\title{
Incentive effect of joint and several liability in fishery cooperatives on regulatory compliance
}

\author{
Bellanger Manuel ${ }^{1,}{ }^{*}$, Holland Daniel S. ${ }^{2}$, Anderson Christopher M. ${ }^{3}$, Guyader Olivier ${ }^{1}$
}

1 Unité d'Economie Maritime UMR 6308 AMURE Ifremer, Univ Brest, CNRS, IUEM Plouzane, France

2 Northwest Fisheries Science Center NOAA Fisheries Seattle Washington, usa

${ }^{3}$ School of Aquatic and Fishery Sciences University of Washington Seattle Washington, usa

*Corresponding author : Manuel Bellanger, email address : $\underline{\text { manuel.bellanger@ifremer.fr }}$

\begin{abstract}
:
Cooperative-based catch share systems can be implemented such that the members of the same fishery cooperative are jointly and severally liable for not exceeding collectively assigned fishing rights. In practice, this means that a regulator can take away catch privileges from an entire cooperative that overruns its collective quota, effectively creating a penalty much larger than what could be recovered with an individual fine. Fishery cooperatives then typically implement their own internal compliance regime that includes monitoring and penalties. This article first reviews compliance practice in cooperative-based catch share systems by examining the commonalities and differences in the way compliance regimes are structured (observation and reporting requirements, penalty scheme, internal enforcement authority and indemnification mechanisms) in a number of internal agreements from fishery cooperatives in North America and in Europe. Based on our review of cooperatives and the literature on compliance, we discuss how incentives to comply may be different for an individual fisherman operating in a fishery cooperative where joint and several liability applies as compared to an individual fishing quota baseline situation without fishery cooperative. Our review suggests that, from the regulators' point of view, joint and several liability can increase the level of compliance for a given enforcement expenditure. However, the regulator cannot rely solely on cooperatives to carry out controls and must ensure that the cooperatives themselves have an interest in setting up an effective monitoring system and will enforce sanctions within the cooperative.
\end{abstract}

Keywords : co-management, compliance regime, enforcement, harvester cooperatives, monitoring, nested institutions 


\section{Introduction}

Problems of non-compliance may undermine the sustainable management of fish stocks (Beddington, Agnew, \& Clark, 2007; Borg, 2008; Bray, 2001; Corveler, 2002; Pauly et al., 2002; Pitcher, Watson, Forrest, Valtýsson, \& Guénette, 2002). A number of studies have empirically demonstrated that 'conventional' economic incentives predominate in fisheries regulatory compliance decisions (Becker, 1968; Furlong, 1991; Hatcher \& Gordon, 2005; Kuperan \& Sutinen, 1998; Nielsen \& Mathiesen, 2003; Sutinen, Gauvin, \& Gordon, 1989; Sutinen, Rieser, \& Gauvin, 1990; Van Hoof, 2010) and deterrence models applied to fisheries have been developed (Anderson, 1989; Anderson \& Lee, 1986; Charles, Mazany, \& Cross, 1999; Hatcher, 2014; Kronbak \& Lindroos, 2006). The key conclusions to be drawn from these concern the probability of detection and sanction, and one of the main policy prescriptions is that the size of the penalty level should be set as high as possible to increase deterrence (Polinsky \& Shavell, 1979, 1992; Shavell, 1993). However, there are a number of factors that can limit the penalty. The penalty imposed on an individual fishing firm cannot exceed the firm's net worth and, in practice, levels of penalties are often much lower because courts are reluctant to execute sanctions perceived as excessive (Kuperan \& Sutinen, 1998). Consequently, it appears that in most fisheries the frequency of inspections (and more generally the level of monitoring) and the level of penalties imposed by the regulator are insufficient to ensure adequate deterrence in comparison to the potential economic payoff from non-compliance with fishing regulations and quotas (Hatcher \& Gordon, 2005; King \& Sutinen, 2010; NAO, 2003; Sumaila, Alder, \& Keith, 2006).

Many authors have supported the idea that 'co-management' systems are a means of improving compliance in fisheries (Gutiérrez, Hilborn, \& Defeo, 2011; Hanna, 1999; Jentoft, 1989; Jentoft \& McCay, 1995; Nielsen, 1994; Nielsen \& Mathiesen, 2003; Nielsen \& Vedsmand, 1997; Ostrom, 1995; Pinkerton, 2011; Van Hoof, 2010). Co-management classically refers to a collaborative process of decision-making combining the capacities and interests of industry organizations such as fishery cooperatives (often referred to as producer organizations in many European countries or as sectors in 
the US Northeast) with the ability of a government agency to implement regulations and provide coordination. Such systems have actually been implemented in many fisheries around the world. Previous studies have often focused on how co-management brings legitimacy to the system, helping to create positive behavioral norms and voluntary compliance (Berkes, 1994; Jentoft, 1989; Kraak, 2011; Nielsen \& Mathiesen, 2003; Ostrom, 1990; Pinkerton, Allain, Decker, \& Carew, 2018; Van Hoof, 2010).

Although fishery cooperatives programs are structured in a variety of ways, many share the characteristic that the members of the same cooperative are jointly and severally liable for not exceeding collectively assigned fishing rights (and sometimes they are jointly and severally liable for other types of violation as well). Joint and several liability is a designation of liability by which members of a group are mutually responsible for the damages caused by one or more members. The potential reasons for the imposition of joint and several liability include that jointly liable parties may serve as insurers for each other, and dealing with situations where the plaintiff cannot determine which of the defendants caused the harm and the defendants are best-positioned to apportion damages amongst themselves (Kornhauser, 2013). Literature on the incentive effects of joint and several liability has mostly focused on recovering damages (Segerson \& Tietenberg, 1992) and how it influences parties to reduce the likelihood of damages (Carvell, Currie, \& Macleod, 2012; Tietenberg, 1989), for example in environmental pollution cases such as those involving Superfund sites in the USA (Klee \& Kornhauser, 2007; Kornhauser \& Revesz, 1994). In general, joint and several liability modifies the risk of insolvency and increases the value of a claim, thereby providing greater incentives for regulatory compliance (Kornhauser, 2013). In the context of fishery cooperatives, joint and several liability usually means that the regulator can hold the members of a cooperative jointly responsible for non-compliance with quota regulations.

This article contributes to the literature on compliance in fisheries by critically evaluating the incentive effect of joint and several liability in a fisheries context and reviewing the response of fisheries 
cooperatives to this additional responsibility and liability. Cooperative-based systems make up about $10 \%$ of rights-based fishery management programs globally and are very common in Europe and the USA (Bonzon, Mcilwain, Strauss, \& Leuvan, 2010). Because joint and several liability for quota overage and for misreporting is a frequent characteristic of catch share systems based on fishery cooperatives, the question of whether and how it may be a means of improving compliance is critical to inform the design of institutions, which has been identified as one of the key challenges of successful fisheries management (Burgess, Clemence, McDermott, Costello, \& Gaines, 2018). The article first presents institutional details on the way compliance regimes are structured in 13 internal agreements from fishery cooperatives in North America and in Europe. Based on this review of compliance practice for fishery cooperatives in catch share systems and a review of relevant literature, we then evaluate and discuss the incentive effect of joint and several liability.

We find that fishery cooperatives typically implement their own internal compliance regime including monitoring and penalties, thus modifying the deterrence scheme from a 'classical' principal-agent problem (regulator watching fishermen; see Vestergaard (2010) for a review of applications of the principal-agent approach in fisheries) into a nested problem (regulator watching cooperatives and cooperatives watching fishermen). Joint and several liability allows for higher penalty levels and may reduce enforcement costs for the regulator, but this may depend on internal arrangements and behavior inside the cooperative. Fishery cooperative members often have a long history of working together and social relationships - strong ties that are commonly referred to as social capital (Pretty, 2003; Putnam, 2000). Social capital can improve behavioral norms and is therefore an important factor in the analysis of the role played by the joint and several liability mechanism in enhancing (or potentially undermining) regulatory compliance. The regulator must also consider the possibility of collusion between the cooperative and its members, i.e. strategic behavior to evade regulations (Frascatore, 1998). To address this issue, the regulator has the option to impose monitoring and enforcement duties on the cooperatives to deter collusion and consolidate the overall compliance regime (Arlen, 2012). 


\section{A review of internal compliance systems used by fishery cooperatives in}

\section{North America and in Europe}

This section describes the way compliance systems are structured in internal agreements or contracts from 13 fishery cooperatives that are responsible for managing collective catch shares. Some of these internal agreements have been provided by cooperative managers while others are available online or have been partially reproduced in the grey literature (e.g. Marine Stewardship Council public certification reports). The main characteristics of the internal compliance systems established in cooperative agreements from six different countries (USA, Canada, France, Netherlands, Denmark, and UK) are presented in Table 1. Although fishery cooperatives are broadly involved in the management of many fisheries worldwide (Ovando et al., 2013), the focus here is on cooperative-based catch share systems where joint and several liability applies, which are mostly found in North America and in Europe. For instance, the scope of this review excludes TURF-based cooperatives that determine their own collective catch limits (Orensanz et al., 2005) as well as private risk pool arrangements formed within individual transferable quota (ITQ) systems and where pool members may be denied quota coverage when they violate the pool internal agreement (Kauer et al., 2018). While this review may not be comprehensive, we were unable to find cases of fishery cooperatives operating under catch shares with joint and several liability outside North America and Europe.

\section{Institutional context}

Fishery cooperative programs in the USA are managed under the National Marine Fisheries Service (NMFS) regulations. Legal actions brought by NMFS against a cooperative are taken to federal district courts that are deemed to have jurisdiction to enforce NMFS regulations. In Canada, the Department of Fisheries and Oceans (DFO) supervises a fishery cooperative program in Nova Scotia frequently referred to as a community management system and has jurisdiction to enforce fisheries-related regulations and legislation. In the European Union (EU), cooperative programs are managed under 
Common Fisheries Policy (CFP) regulations and are implemented at the Member State level. Each Member State has jurisdiction and responsibility to enforce the CFP regulations.

One interesting aspect of cooperative programs is that the regulator can design the rules such that members of the same cooperative are jointly and severally liable for certain types of offenses. All the cooperative agreements listed in the Table 1 contain joint and several liability for quota overages. In practice, if a cooperative exceeds one of its quotas, the regulator may impose a permanent or temporary reduction of fishing opportunities for the whole cooperative including stop fishing orders, loss of quota units, and termination of the cooperative authorization. In the USA, the members of the North East fishery sectors are also jointly and severally liable for fines, penalties and forfeitures related to discarding of legal-sized fish and misreporting of catch landings and discards. On the West coast, Whiting Mothership Cooperative (WMC) members may be held jointly and severally liable for noncompliance with the fishery observer requirements and for violations of the cooperative's non-whiting species management rules.

\section{Observation}

The contracts of the WMC, Alaska Catcher-Processor cooperatives Incentive Plan Agreement (CPIPA), Mothership cooperatives Incentive Plan Agreement (MSIPA), and Shoreside cooperatives Incentive Plan Agreement (SIPA) require Federal observers to be placed on all vessels in the cooperative at all times. Each cooperative is responsible for the cost of these observers. Having $100 \%$ observer coverage has enabled cooperatives in US Pacific Coast and Alaskan fisheries to develop bycatch reduction programs requiring vessels to meet standards, follow specified bycatch avoidance practices, and share information (Holland, 2018; Kauer et al., 2018; Little, Needle, Hilborn, Holland, \& Marshall, 2015). Some cooperatives have partial observer coverage and an additional system to monitor landings. For instance, the Fundy fixed gear Community Harvest Plan (FCHP) requires to have at least $10 \%$ industryfunded observer coverage and a 'hail-out hail-in' monitoring program operated by an independent private company covering $100 \%$ of landings to verify unloading amounts at the dockside. In 
cooperatives that do not contractually require members to carry observers, members are typically required to have their fishing activity monitored at-sea with some electronic equipment that can include GPS and remote cameras. The Northeast Fishery Sector II (NEFS II), Georges Bank Cod Hook Sector (GBCHS), and Brown Shrimp producer organization Management Plan (BSMP) also have dockside observers that monitor landings at pre-approved landings stations and pre-approved times.

\section{Reporting}

All the cooperative agreements reviewed require some form of accurate reporting. Besides observation, an accountable system of reporting seems to provide a critical means to ensure compliance with the cooperative's rules. Most cooperatives require two complementary reporting elements on a timely basis: catch logs and dealers reports. Besides, cooperative typically have a monitoring agent whose job is to track the cooperative quota consumption but also to notify apparent violations that could be detected out of the catch logs and dealers reports. Regulations may require that the monitoring agent is a third-party to ensure neutrality (as in WMC, CPIPA, and FCHP).

\section{Penalty structures}

A critical element of the cooperative agreements is the penalty structure. In the USA, courts generally will not enforce punitive penalties in contracts that are meant to be like fines, however if penalties are related to damages they may be upheld. Penalties for non-compliance with cooperative rules are in fact included in almost all of the cooperative contracts in North America and in Europe. The complexity of this structure varies by cooperative, ranging from stipulated penalties to graduated sanctions.

Overharvest penalties can be proportional to the ex-vessel value of landings (e.g. $300 \%$ in WMC, $100 \%$ in Pêcheurs de Bretagne Producer Organization (PDBPO) and in From Nord Producer Organization (FNPO)) or equal to a forfeiture amount defined per species multiplied by the number of metric tons harvested in excess of quota. Penalties in quota tons for the next year or permanent loss of quota units are also frequently used by cooperatives. Most cooperatives are also allowed to impose stop fishing orders. The Cobrenord Producer Organization (CNPO) cannot impose monetary penalties on its 
members and uses seizure of catches that are in contravention with its agreements to sanction offending members. This seems less dissuasive than monetary penalties as it is only applicable when violators are caught in the act.

A refundable security deposit to cover potential damages may be requested by the fishery cooperative upon joining the cooperative (as in the Thorupstrand Coastal Fishermen's Guild (TCFG)) or during the course of the fishing season if the likelihood of quota overrun is serious (as in FNPO). While the amount of the deposit is usually less than the penalty a vessel may actually incur, deposits can contribute to making threats of penalties more meaningful.

Generally, penalty structures also include graduated sanctions to deal with infractions such as misreporting landings, illegally discarding, non-compliance with gear, time and area restrictions. The degree of sanction imposed increases with the frequency of infractions and the severity of an infraction, and most cooperative agreements establish the expulsion of the offending member as one of the ultimate sanctions.

\section{Internal enforcement authority}

The internal enforcement authority is usually a disciplinary committee appointed by the cooperative management board or the board itself. In determining sanctions, the enforcement authority evaluates the infraction history of the offending member and the severity of a given infraction. Infractions may be dealt with anonymously to ensure objectivity in the sanctions process. In FCHP, violations used to be reviewed anonymously by an infraction committee consisting of different cooperative members every time the committee met. However, in some cases, sanctioned fishermen were able to ask for an appeal of the sanction and be heard by the committee. This system was changed to automatic sanctions in 2006 because committee members were uncomfortable with making appeal judgements when anonymity was lost. 


\section{Indemnification}

One of the aspects where cooperative agreements may greatly differ is whether members who suffered losses due to the actions of an offending member are indemnified. In NEFS II, GBCHS, WMC, and FNPO, damages that are awarded to the cooperative are to be disbursed on a pro-rata basis to those members who have harvested less than their allocations. This means that indemnification against quota overage by other members can be found in some cooperatives on both coasts of the USA and in some EU producer organizations as well. To the contrary, CPIPA and SIPA explicitly specify that there can be no damages associated with someone shutting down the fishery early. They however include indemnification against legal fees and governmental penalties. The other cooperative agreements do not mention indemnification, which suggests that members cannot sue each other for damages. WMC specifies that members cannot sue the cooperative, the manager, and the monitoring agent in order to let them exercise their independent responsibility and judgment in fulfilling the terms of the agreement.

\section{Available compliance data and information}

WMC, CPIPA, MSIPA and SIPA have publicly available annual reports intended to disclose all information required in US Federal Regulations, including a description of any actions taken by the cooperative in response to any vessels that exceeded their allowed catch and bycatch. Between 2012 and 2017, CPIPA, MSIPA and SIPA cooperatives consistently reported that none of their vessels were found in violation of their internal agreement and that no enforcement actions were taken against their members. On the same period, WMC systematically reported having to enforce cease-fishing orders to vessels that reached their collective share of the bycatch prior to harvesting their whiting allocation and that no violations of the internal agreement were observed.

The fifteen US Northeast multispecies fishery sectors are also required to submit year-end reports including any violations of the sector operation plans or regulations. For most sectors and most years between 2010 and 2017, the sectors reported that they had no violations of federal regulations or sector rules. The remainder reported a variety of violations of sector rules including refusals to take 
observers on board, excessive discard rates or discarding of legal size fish, not providing required catch data in a timely manner, and use of a particular gear outside allowed areas. Almost all of these reported to have been first offenses and the offender received only a warning. Over the years, a total of six monetary penalties (for violation of discards rules or violation of gear restrictions) have been reported by sectors, of which five were assessed in the first couple of years following the implementation of the sector program. In one instance, two vessels were expelled from a sector due to quota overages, risk of joint and several liability, and continued fishing activity after a stop fishing order was issued. Finally, one sector's operational plan was disapproved in 2017 and 2018 after one of its members was arrested and charged with criminal offenses including false labeling and identification, falsifying federal records, bulk cash smuggling, and tax evasion (District of Massachusetts, 2017; National Archives and Records Administration, 2017).

The Northeast multispecies fishery sectors year-end reports also contain anecdotal evidence of the effect of joint and several liability on monitoring behavior within sectors, such as members contacting their sector manager regarding their concerns of rumors of potential misreporting of catch by another member. The sector reports describe investigations of these issues by internal enforcement committees and, in some instances where the determination of misreporting was not conclusive, how the sector and the involved member worked out an agreement on additional landing observation requirements in order to stop the rumors. Multiple sectors also reported issuing stop-fishing orders to members who had reached or exceeded their individual catch limits in order to avoid quota overages. According to a Marine Stewardship Council certification report, overall compliance by BSMP members is considered to be good with no systematic non-compliance issues reported (Addison, Gaudian, \& Knapman, 2017). In particular, gear specifications and area closures are considered to be implemented successfully. This report also mentions that the cooperative has issued fines against particular vessels for breaching of the internal agreement, including one instance of a repeat infringement and increased fine. However, the report acknowledges that, while there is qualitative evidence that sanctions to deal 
with non-compliance exist and are applied, there is no clear demonstration that the monitoring, control and surveillance mechanisms ensure effective deterrence.

For all the other cooperatives reviewed, there is no publicly available information regarding individual compliance with internal agreements.

\section{Discussion}

\section{Incentive effect of joint and several liability}

The typical starting point for understanding how economic incentives to comply may be different for an individual fisherman operating in a fishery cooperative where joint and several liability applies as compared to an ITQ baseline situation (where there is no fishery cooperative structure) is to compare monetary costs and benefits of the compliance/violation decision following a utilitarian model of fishermen's behavior found in the economics of crime literature (Becker, 1968; Block \& Heineke, 1975; Ehrlich, 1972, 1973). Typically, the regulator has a certain probability of detecting a violation, and imposes a penalty if a violation is detected. In the ITQ homo economicus baseline case (without cooperative structure), individual fishermen comply when the additional benefit from non-compliance is less than the probability of detection by the regulator multiplied by the amount of the fine (Becker, 1968).

In the fishery cooperative case where joint and several liability for quota violations or misreporting applies, the regulator can impose a penalty on the entire cooperative if it overruns its collective quota. The cooperative can then implement some internal monitoring mechanism aiming at incentivizing regulatory compliance. Implementation of such an internal compliance regime is in fact required by the regulator in most cooperative-based catch share systems. The cooperative has a probability of detecting a violation that can be greater than the probability of detection by the regulator. For example, members of the same cooperative typically share the same fishing grounds and landing docks and thus are well-positioned to detect a violation from one of their peers. Fishermen also often engage 
in social relationships with their peers to share fishing-related knowledge including information to support collective monitoring and enforcement (Grafton, 2005; Jentoft, McCay, \& Wilson, 1998; Sekhar, 2007). In addition, the cooperative managers may have access to information on the fishing activities of their members that are not necessarily known to the regulator (Abdullah, Kuperan, \& Pomeroy, 1998). In some cases, the regulator may also be able to help reduce the watching cost for the cooperative, for example by allowing the cooperative to have access to information collected by observers or electronic observing equipment. This is in fact done with information from federal observers in US Pacific Coast and Alaskan fisheries who contract with a third party provider that collates information from observers in near real time and produces information products to support bycatch avoidance as well as ensuring cooperative vessels are complying with the cooperatives rules (e.g. time-area closures) (Little et al., 2015).

When internal quota allocations for cooperative members are heterogeneous, which is the case for all cooperatives that we reviewed, there is typically an asymmetry among cooperative members in their expected gains from non-compliance. Under the joint and several liability mechanism, the cooperative members that have no (or lower) economic incentive to violate will have an interest in supporting an internal monitoring system within the cooperative to ensure other members that might have greater incentives for noncompliance are deterred so as to avoid sanctions imposed by the regulator on the whole cooperative. This would make potential violation less profitable and increase incentives to comply provided that the level of internal penalty is greater than the expected benefit from noncompliance (Becker, 1968). This economic intuition is supported by the results of a simple gametheoretic model presented in the Supplementary Appendix. In addition, several behavioral economics studies have identified that asymmetric payoffs in positive-sum games induce a fairness norm leading to a middle-way solution where aggregate payoffs are not maximized (Ahn, Lee, Ruttan, \& Walker, 2007; Budescu, Rapoport, \& Suleiman, 1990; Kagel, Kim, \& Moser, 1996; Parisi, 2000). Instead, individuals tend to make strategic decisions leading to outcomes in favor of more even distributions of income. Including negative payoffs in possible outcomes appears to further strengthens this result 
(Beckenkamp, Hennig-Schmidt, \& Maier-Rigaud, 2007; Kahnemann \& Tversky, 1979; Tversky \& Kahnemann, 1981). This is relevant to the case of fishery cooperatives with joint and several liability where compliant members may have an impetus to support an internal monitoring system to avoid having to face a penalty because of violations committed by other cooperative members. Thus, assuming that internal penalties can be imposed independent of detection by the regulator and that there is sufficient asymmetry among cooperative members in terms of expected benefit from noncompliance, joint and several liability may allow the regulator to induce greater compliance for a given enforcement expenditure.

The case of the Dutch fisheries, where a co-management regime was laid on top of a pre-existing individual quota system (Hoefnagel \& de Vos, 2017), constitutes perhaps the most convincing empirical evidence of the incentive effect of joint and several liability on rule compliance. Indeed, self-organized groups of fishers (with joint and several liability, internal monitoring and penalty systems) were introduced well after the development of the ITQ system, which makes the before-after comparison quite meaningful. According to Van Hoof (2010), the introduction of co-management groups enabled a $45 \%$ reduction in monitoring costs for the regulator and concurrently a $90 \%$ decrease in the number of registered infringements in the Dutch fisheries. The co-management arrangements induced a shift in the economic and social normative rationales from a situation where non-compliance was the rule to a management system considered as a best-practice model by the EU (Hentrich \& Salomon, 2006; Van Hoof, 2010).

Some of the internal compliance systems that we reviewed included indemnification against regulator penalties. Indemnification occurs when the regulator detects a violation and imposes a penalty on the whole cooperative, but ultimately the penalty is entirely supported by the violator who is required to indemnify (compensate) the other cooperative members. Indemnification could effectively negate the beneficial effect of joint and several liability to some degree since it insulates cooperative members from penalties due to actions of other cooperative members. In that case, the incentive effect of joint and several liability would be largely inconsequential from the regulator's point of view. However, if 
the penalty exceeds the offending party's ability to compensate the other members of the cooperative, they will still have to share at least part of the costs of the penalty, so they may still have incentives to deter noncompliance by other members.

The institutional details presented in our review of internal compliance regimes showed that most fishery cooperatives that are jointly and severally liable for quota overages have the ability to impose penalties or fines on members for breaching quota (as well as other internal cooperative rules). In some of the internal agreements, fines increase with $2^{\text {nd }}$ or $3^{\text {rd }}$ offences. This could have the effect of creating or increasing asymmetry in payoffs for different cooperative members even when quota allocations are similar. As explained earlier, asymmetry is a good property as it strengthens incentives of internal monitoring. Regulators may want to require and review internal cooperative compliance programs as a condition of allocating quota to a cooperative in order to complement external enforcement and strengthen overall compliance regimes.

Data and information regarding compliance in fisheries are generally hard to come by, and quantifying empirically the effect of joint and several liability on compliance appears extremely challenging. Even if reliable data on the level compliance in a cooperative-based catch share system was available, such quantitative analysis would still require constructing a credible counterfactual (i.e., what would be the level of compliance without cooperatives), which is a particularly difficult task (Helm \& Sprinz, 2000). Thus, current empirical evidence of the incentive effect of joint and several liability in fishery cooperative is essentially anecdotal. Our review showed that annual reports available for US West Coast and Alaskan cooperatives consistently indicate that no violations of their internal agreement were observed. Some of these reports also mention enforcing stop-fishing orders to avoid bycatch overruns, suggesting that these cooperatives have successfully implemented effective internal compliance regimes. For the US Northeast multispecies fishery sectors, annual sector reports describe internal investigations that were undertaken in some cases that reveal errors in reported data (e.g. discards were overestimated) or difficulties that sector members had with compliance (e.g. discarding legal size fish they feared might be undersize) or misunderstanding of requirements and procedures 
(e.g. observer refusals). In one instance, a sector reported to have expelled two of its members for quota overages and non-compliance with stop fishing orders, invoking the risk of joint and several liability to motivate this decision. Internal investigations and cooperation with regulators in undertaking them arguably provided opportunities to improve the overall compliance system. They also demonstrate that most sectors have active internal monitoring and investigatory systems in place to support compliance. Likewise, an independent assessment of the North Sea brown shrimp fishery considered that overall compliance by cooperative members was good with no systematic noncompliance issues (Addison et al., 2017). The case of the Dutch fisheries documented by Van Hoof (2010) indicates that introduction of a system based on cooperative allowed increasing compliance while reducing monitoring costs. While limited in scope and not fully conclusive, these pieces of empirical evidence tend to support the economic argument that joint and several liability is potentially beneficial to compliance.

\section{Incentive effect of other-regarding preferences}

There is an extensive literature supporting the idea that Becker's framework (Becker, 1968) for explaining criminal activity (i.e. models relying on costs and revenues associated with illegal behavior) provides an incomplete model of regulatory compliance in fisheries as it does not account for the social factors that influence the behavior of agents (Boonstra, Birnbaum, \& Björkvik, 2017; Cardenas, 2011; Eggert \& Lokina, 2010; Hatcher, Jaffry, Thébaud, \& Bennett, 2000; Jackson et al., 2012; Nielsen, 2003; Sutinen \& Kuperan, 1999). There is also some evidence that self-organization and co-management systems, which include fishery cooperatives, may be a means of strengthening cooperation and social capital (Defeo et al., 2016; Hilborn, 2007; Jentoft, 2000; Libecap, 1994; Ostrom, 1990; Soma, van Tatenhove, \& van Leeuwen, 2015). Behavioral economics theories, that typically substitute a social utility for expected gains to account for other-regarding preferences in social groups (Bolton, 1991; Camerer, 2003), offer interesting frameworks for including some social capital component on top of standard economic incentives. For example, it has been shown that members of a social group tend to care about their own and relative payoffs (Charness \& Rabin, 2002; Fehr \& Schmidt, 1999). By applying 
this reciprocity mechanism in the context of fishery cooperatives, the utility of a fisherman that violates the rules for an additional economic benefit is decreased by 'guilt' whereas the utility of fishermen that have no incentive to violate is decreased by 'envy' when the former chooses a course of action that is considered as unfair behavior. The intrinsic motivations of the lower-payoff fishermen to watch their peers are increased by their aversion to unfair behavior and disadvantageous inequality, which in turn induces a lower level of violation by the fishermen with higher payoff. Concurrently, intrinsic motivations to violate are determined by a combination of utilities from one's own expected gains and disutilities from choosing a course of action that produces negative effects on others. In general, otherregarding preferences tend to magnify the incentive effect of joint and several liability, which has the potential to substantially improve compliance as compared to the ITQ baseline situation. This holds even when the expected additional benefit from violating is large as inequality aversion increases the level of watching and decreases the utility derived from having higher economic gains (see the Supplementary Appendix for a more detailed evaluation of the role of other-regarding preferences on strengthening compliance in a stylized fishery cooperative setting).

Such social motivations are probably more likely when members of a cooperative have social relationships and histories of working together (i.e. social capital). Notably, most fishery cooperatives are self-forming and have the ability to exclude unwanted members. They are often formed on the basis of existing relationships such as common membership in an association. Some level of trust is probably required for members to agree to join a cooperative with joint and several liability, but this characteristic also may help strengthen incentives for compliance. While these elements suggest that regulators may want to allow cooperatives to choose and exclude members, care must also be taken to ensure that the members' interests are not so closely aligned that they have the incentive to collude to evade regulations. 


\section{Aligning the regulator and cooperative incentives}

While joint and several liability appears to have the potential to increase regulatory compliance in catch share systems, the regulator must ensure that the cooperatives have incentives to implement and enforce an effective internal compliance regime (Frascatore, 1998). In a cooperative where no member has an interest in having strict internal rules enforced (e.g. if they all expect large benefits from non-compliance), then the cooperative as an entity has little incentive to implement such compliance regime. Also, if the cooperative members perceive the regulations as illegitimate, the cooperative may have mixed incentives. That is, if the incentives of the cooperative and the regulator are not aligned, its primary concern will be that no member gets caught doing something wrong, which happens either when all members comply or when the violators do not get caught. The latter implies the cooperative may develop 'inside strategies' where members can share information on how to avoid getting caught, making the regulator's job harder. Therefore, if there is no heterogeneity among cooperative members, it is unclear that the regulator gains something from having cooperatives with a joint and several liability mechanism. For instance, if one entity owns or controls all the vessels in a cooperative, the impetus to comply of the joint and several liability mechanism is negated. This suggests that a reasonable ownership cap should be instituted to prevent complete control or dominance of one party in a cooperative.

The literature on corporate crime liability (Arlen, 1994; Arlen \& Kraakman, 1997; Polinsky \& Shavell, 1999) offers interesting insights in terms of institutional designs that are able to induce internal policing. It was determined that optimal deterrence of crimes by employees committed in the scope of employment is achieved by combining: a 'duty-based' regime under which firms are obligated to undertake monitoring, self-reporting, and cooperation with the regulator, and are subject to a sanction for violating any one and each of these duties; sanctions imposed on individual wrongdoers; and a 'residual' sanction imposed on firms when members do commit violations to incentivize them to adopt adequate prevention measures (Arlen, 2012). While this threefold deterrence scheme may not be directly applicable to joint and several liability in a fisheries context, the principle of a duty-based 
regime can be used to make sure that the benefit for a cooperative to engage in monitoring is greater than when it does not. Interestingly, US West Coast and Alaskan cooperatives are using similar principles internally by imposing penalties on hired captains for violating rules such as area closures while holding vessel owners liable for the consequential damages arising out of hired captains' negligence or willful misconduct. This serves to dissuade noncompliance by captains, who have financial incentives to keep catch rates high. It may also help deter collusion between vessel owners and hired captains.

A recent criminal case involving the largest vessel owner in the New England groundfish industry, Carlos Rafael (locally known as "The Codfather"), illustrates a number of critical points raised in this discussion. Rafael had the largest quota share for many groundfish species in New England, and also leased quota from many smaller quota holders. He essentially controlled one of the Northeast fishery sectors ("NEFS 9") and his assets were worth tens of millions of dollars. He was arrested in 2016 for violations of fishing quota regulations and pleaded guilty in March 2017 to 28 offenses, including conspiracy, false labeling of fish, bulk cash smuggling, tax evasion and falsifying federal records (see United States v. Rafael, Criminal Action No. 16-10124-WGY (District of Massachusetts, 2017)). He was sentenced to 46 months in prison, 3 years supervised release, and a $\$ 200,000$ fine. During his order, the judge said that, while the fisherman's corrupted scheme was designed for his own benefit, it also impaired the ability of regulators to determine appropriate quota to set (Bonner, 2017). This supports the argument that if the cooperative's and regulator's interests are not aligned, then the cooperative may develop inside strategies.

In addition to the sentence, the US government requested forfeiture of the vessels owned by Rafael and their accompanying fishing permits. However, the court was reluctant to issue a judgement ordering forfeiture of more than 4 vessels (out of the 28 owned by Rafael) because the judge suspected seizing more vessels would infringe on the excessive fines clause of the US constitution's Eighth Amendment (District of Massachusetts, 2017). This shows that, even when an individual is charged 
with significant criminal offenses, the maximum fines invoked by courts may be much lower than his assets. More recently, the government announced having filed a charging document in order to bring civil penalties to Rafael to further aid the victims of his crimes. The civil action seeks to revoke all his fishing permits and impose $\$ 983,528$ in penalties (Heckwolf, 2018). The notice was concurrently addressed to 34 entities related to Rafael's operations and establishes that the civil monetary penalties were assessed jointly and severally, holding all entities owned or controlled by Rafael liable for the total amount of the penalty. In this case, the application of joint and several liability may effectively allow recovering greater damages than what was initially ordered by the court.

While an owner of multiple vessels can operate his vessels under multiple individual companies, the rules for forming a sector as specified in the Northeast Multispecies Fishery Management Plan require that there should be at least 3 distinct owners in a sector. This requirement is important to reduce the likelihood of collusion within a cooperative. However, in the Codfather case, Rafael, who was the owner of one of the largest commercial fishing businesses on the US East Coast and president of the NEFS 9 sector at the time, essentially controlled the entire sector. In this case, the potential benefit of an internal compliance system with monitoring and penalties is negated, but joint and several liability can still increase the size of the penalty that can be recovered by reducing the risk of insolvency of individual fishing businesses. However, a rigorous evaluation of the incentive effect of joint and several liability in the case of single ownership of multiple entities, which could be addressed with a model of corporate crime liability (Arlen, 2012), is beyond the scope of this article.

\section{Conclusions}

Perhaps the most fundamental compliance related benefit of cooperative-based catch share systems with joint and several liability is that the size of the penalty that can be recovered from a cooperative is likely to be higher than from an individual in an ITQ system. The latter is limited by the individual's net worth and potentially by limits on the size of fines courts will allow. The ability of the regulator to take away catch privileges for one or more years from the entire cooperative may effectively create a 
penalty much larger than could be recovered with an individual fine. Enabling a higher maximum fine can increase the level of compliance for a given probability of observing a violation and thereby increase compliance for a given enforcement expenditure. This result is highly relevant to address the question of how to ensure better reporting, which is one of the very significant concerns related to the European fisheries adopting the discard ban of the new EU common fisheries policy and the push to monitor total catch (Veiga et al., 2016).

Full compliance with fishery regulations cannot generally be expected unless the expected penalty that may be imposed by the regulator is greater than the expected gains of non-compliance for all individuals. When the regulator cannot support the costs of monitoring and enforcement that are necessary to create such conditions or the size of fines is limited, the fishery cooperatives approach, including joint and several liability mechanisms, is a potential means of improving compliance or reducing the level and cost of monitoring required to assure compliance. Compliance may be enhanced if social pressures strengthen incentives for compliance with internally agreed rules and behavioral norms. Social capital is a critical component of fisheries co-management systems that influences the formation of fishery cooperatives and the development, effectiveness, and sustainability of internal compliance regimes which rely on trust and reciprocity. Regulators may be able to increase compliance rates and reduce their own compliance expenditures by ensuring cooperatives have well designed internal compliance systems. They may also be able to make these systems more effective and desirable to cooperatives if they can help reduce the cooperatives costs of observing non-compliance. This might involve sharing of information from observers or electronic observation equipment, though this may be problematic if the cooperative was inclined to use this information to reduce detection of non-compliance by regulators.

Our review of compliance practice for fishery cooperatives and the literature on compliance suggests that internal monitoring and reporting requirements, as well as the penalty structure, are critical components of internal agreements and contracts. In many cases, penalties are ramped up for $2^{\text {nd }}$ or 
$3^{\text {rd }}$ violations, and fishermen might be more likely to be watched and thus caught. This should help improve compliance, both for ITQs and cooperatives. It also can create a source of asymmetry in the net benefit from non-compliance as a fisherman that has been caught violating endure a penalty that is higher than the fishermen that have not. Asymmetry in payoffs for noncompliance may be important to ensure cooperative members do not collude and support an effective internal compliance regime.

The scope of our empirical study is limited to 13 fishery cooperatives from 6 countries that are all in North America and Europe. While we did not find cases of fishery cooperative operating with joint and several liability outside these regions, we see no reason to expect different results for similar cooperative-based catch share systems in other regions. In general, as the main compliance-related benefit of joint and several liability is to increase the expected penalty relative to what can be recovered with individual fines, we anticipate that joint and several liability can be useful for regulators in countries where the size of the penalty is limited or where monitoring is difficult; conversely, joint and several liability is potentially less useful in countries where the penalty is not limited or where the probability of detecting non-compliance with fishery regulations is high. We might expect joint and several liability to be particularly useful in developing countries or fisheries with many small vessels or landing ports where enforcement may be limited and/or expensive.

When cooperatives operate with joint and several liability, the regulator's problem changes from a principal-agent problem (regulator-fisher) to a nested problem (regulator-cooperative-fisher). The regulator must consider the possibility of collusion with the cooperative, but can also strengthen the overall compliance regime by imposing duties on the cooperative. By complementing the typical enforcement regime focused on monitoring and penalizing noncompliance of individual fishers with an internal compliance system at the cooperative level, regulators may be able to significantly improve fisheries compliance outcomes. In particular, it appears that joint and several liability is a critical component of fishery cooperative programs that has important policy implications. The evaluation of its effects and available empirical evidence underscore that joint and several liability is mostly beneficial to compliance and particularly relevant to situations where the regulator is unable to ensure 
adequate deterrence by means of traditional individual fines. However, as the case of the Codfather shows, the regulator cannot rely solely on having the cooperatives ensure that there is compliance. Beyond joint and several liability, the design of the catch-share system must also ensure that the cooperatives have incentives to monitor their members' activities and enforce sanctions within the cooperative.

\section{Acknowledgements}

We thank the reviewers for their insightful comments on earlier versions of this manuscript. The authors have no conflict of interest to declare. 


\section{References}

Abdullah, N. M. R., Kuperan, K., \& Pomeroy, R. S. (1998). Transaction Costs and Fisheries Comanagement. Marine Resource Economics, 13(2), 103-114.

Addison, J., Gaudian, G., \& Knapman, P. (2017). MSC Sustainable Fisheries Certification: North Sea Brown Shrimp, Final Report.

Ahn, T. K., Lee, M., Ruttan, L., \& Walker, J. (2007). Asymmetric payoffs in simultaneous and sequential prisoner's dilemma games. Public Choice, 132(3-4), 353-366.

Anderson, L. G. (1989). Enforcement issues in selecting fisheries management policy. Marine Resource Economics, 6(3), 261-277.

Anderson, L. G., \& Lee, D. R. (1986). Optimal Governing Instrument, Operation Level, and Enforcement in Natural Resource Regulation: The Case of the Fishery. American Journal of Agricultural Economics, 68, 678-690. https://doi.org/10.2307/1241552

Arlen, J. (1994). The potentially perverse effects of corporate criminal liability. The Journal of Legal Studies, 23(2), 833-867.

Arlen, J. (2012). Corporate criminal liability: theory and evidence. Law \& Economics Research Paper Series, $11-25$.

Arlen, J., \& Kraakman, R. (1997). Controlling Corporate Misconduct: an Analysis of Corporate Liability Regimes. New York University Law Review, 72(4).

Beckenkamp, M., Hennig-Schmidt, H., \& Maier-Rigaud, F. (2007). Cooperation in Symmetric and Asymmetric Prisoner's Dilemma Games (Max Planck Institute for Research on Collective Goods No. 2006/25). Bonn.

Becker, G. S. (1968). Crime and Punishment: An Economic Approach. Journal of Political Economy, 76(2), 169-217. https://doi.org/10.1086/259394

Beddington, J. R., Agnew, D. J., \& Clark, C. W. (2007). Current Problems in the Management of Marine 
Fisheries. Science, 316(5832), 1713-1716. https://doi.org/10.1126/science.1137362

Berkes, F. (1994). Co-management: bridging the two solitudes. Northern Perspectives, 22(2-3), 1820.

Block, M. K., \& Heineke, J. M. (1975). A labor theoretic analysis of the criminal choice. The American Economic Review, 65(3), 314-325.

Bolton, G. E. (1991). A comparative model of bargaining: Theory and evidence. The American Economic Review, 81(5), 1096-1136. https://doi.org/10.2307/2006908

Bonner, M. (2017). Questions linger despite judge ordering forfeiture of Carlos Rafael permits. Retrieved December 2, 2017, from http://www.southcoasttoday.com/news/20171011/questions-linger-despite-judge-orderingforfeiture-of-carlos-rafael-permits

Bonzon, B. K., Mcilwain, K., Strauss, C. K., \& Leuvan, T. Van. (2010). Catch Share Design Manual: A Guide for Managers and Fishermen. Environmental Defense Fund. New York, Environmental Defense Fund. Retrieved from http://hdl.handle.net/10535/7071

Boonstra, W. J., Birnbaum, S., \& Björkvik, E. (2017). The quality of compliance: investigating fishers' responses towards regulation and authorities. Fish and Fisheries, 18(4), 682-697. https://doi.org/10.1111/faf.12197

Borg, J. (2008). Developing a culture of compliance is key to sustainable and equitable fisheries. Press Release EC DGMARE, 18.

Bray, K. (2001). A global review of illegal, unreported and unregulated fishing. FAO Fisheries Report (FAO).

Budescu, D. V., Rapoport, A., \& Suleiman, R. (1990). Resource dilemmas with environmental uncertainty and asymmetric players. European Journal of Social Psychology, 20(6), 475-487.

Burgess, M. G., Clemence, M., McDermott, G. R., Costello, C., \& Gaines, S. D. (2018). Five rules for 
pragmatic blue growth. Marine Policy, 87, 331-339.

Camerer, C. F. (2003). Behavioral Game Theory: Experiments in Strategic Interaction. Princeton University Press. https://doi.org/10.1016/B978-0-12-396959-0.00001-X

Cardenas, J. C. (2011). Social Norms and Behavior in the Local Commons as Seen Through the Lens of Field Experiments. Environmental and Resource Economics, 48(3), 451-485. https://doi.org/10.1007/s10640-010-9452-8

Carvell, D., Currie, J., \& Macleod, W. B. (2012). Accidental death and the rule of joint and several liability. RAND Journal of Economics, 43(1), 51-77. https://doi.org/10.1111/j.17562171.2012.00158.x

Charles, A. T., Mazany, R. L., \& Cross, M. L. (1999). The Economics of Illegal Fishing: A Behavioral Model. Marine Resource Economics, 14(2), 95-110. https://doi.org/10.2307/42629256

Charness, G., \& Rabin, M. (2002). Understanding Social Preferences with Simple Tests. The Quarterly Journal of Economics, 117(3), 817-869.

Corveler, T. (2002). Illegal, Unreported and Unregulated Fishing, Taking Action for Sustainable Fisheries. WWF New Zealand, Wellington.

Defeo, O., Castrejón, M., Pérez-Castañeda, R., Castilla, J. C., Gutiérrez, N. L., Essington, T. E., \& Folke, C. (2016). Co-management in Latin American small-scale shellfisheries: Assessment from longterm case studies. Fish and Fisheries, 17(1), 176-192. https://doi.org/10.1111/faf.12101

District of Massachusetts, U. S. D. C. (2017). U.S. v. Rafael, Criminal Action No. 16-10124-WGY. Retrieved January 31, 2018, from https://www.leagle.com/decision/infdco20171011h94

Eggert, H., \& Lokina, R. B. (2010). Regulatory compliance in Lake Victoria fisheries. Environment and Development Economics, 15(2), 197-217.

Ehrlich, I. (1972). The deterrent effect of criminal law enforcement. The Journal of Legal Studies, 1(2), 259-276. 
Ehrlich, I. (1973). Participation in Illegitimate Activities: A Theoretical and Empirical Investigation. Journal of Political Economy, 81(3), 521-565. https://doi.org/10.1086/260058

Fehr, E., \& Schmidt, K. M. (1999). A theory of fairness, competition, and cooperation. The Quarterly Journal of Economics, (August). https://doi.org/10.3929/ethz-a-004372667

Frascatore, M. R. (1998). Collusion in a three-tier hierarchy: Credible beliefs and pure self-interest. Journal of Economic Behavior and Organization, 34(3), 459-475. https://doi.org/10.1016/S0167-2681(97)00079-6

Furlong, W. J. (1991). The deterrent effect of regulatory enforcement in the fishery. Land Economics, 67(1), 116-129.

Grafton, R. Q. (2005). Social capital and fisheries governance. Ocean and Coastal Management, 48(910), 753-766. https://doi.org/10.1016/j.ocecoaman.2005.08.003

Gutiérrez, N. L., Hilborn, R., \& Defeo, O. (2011). Leadership, social capital and incentives promote successful fisheries. Nature, 470(7334), 386-389. https://doi.org/10.1038/nature09689

Hanna, S. S. (1999). Strengthening governance of ocean fishery resources. Ecological Economics, 31(2), 275-286. https://doi.org/10.1016/S0921-8009(99)00084-1

Hatcher, A. (2014). Implications of a Discard Ban in Multispecies Quota Fisheries. Environmental and Resource Economics, 58(3), 463-472. https://doi.org/10.1007/s10640-013-9716-1

Hatcher, A., \& Gordon, D. (2005). Further investigations into the factors affecting compliance with UK fishing quotas. Land Economics, 81(1), 71-86.

Hatcher, A., Jaffry, S., Thébaud, O., \& Bennett, E. (2000). Normative and Social Influences Affecting Compliance with Fishery Regulations. Land Economics, 76(3), 448-461. https://doi.org/10.2307/3147040

Heckwolf, J. (2018). Case NE1707582, Carlos Rafael, et al. Notice of violation and assessment, notice of permit sanctions \& notice of intent to deny permits. Retrieved January 31,2018 , from 
http://static.djlmgdigital.com.s3.amazonaws.com/nbt/southcoasttoday/graphics/pdf/011118_ NOAAcivil_Rafael.pdf

Helm, C., \& Sprinz, D. (2000). Measuring the effectiveness of international environmental regimes. Journal of Conflict Resolution, 44(5), 630-652.

Hentrich, S., \& Salomon, M. (2006). Flexible management of fishing rights and a sustainable fisheries industry in Europe. Marine Policy, 30(6), 712-720. https://doi.org/10.1016/j.marpol.2005.11.003

Hilborn, R. (2007). Managing fisheries is managing people: What has been learned? Fish and Fisheries, 8(4), 285-296. https://doi.org/10.1111/j.1467-2979.2007.00263_2.x

Hoefnagel, E., \& de Vos, B. (2017). Social and economic consequences of 40 years of Dutch quota management. Marine Policy, 80, 81-87. https://doi.org/10.1016/j.marpol.2016.09.019

Holland, D. S. (2018). Collective Rights-Based Fishery Management A Path to Ecosystem-Based Fishery Management. Annual Review of Resource Economics, 10, 469-485. https://doi.org/10.1146/annurev-resource-100517-023110 Jackson, J., Bradford, B., Hough, M., Myhill, A., Quinton, P., \& Tyler, T. R. (2012). Why do people comply with the law? Legitimacy and the influence of legal institutions. British Journal of Criminology, 52(6), 1051-1071.

Jentoft, S. (1989). Fisheries co-management. Delegating government responsibility to fishermen's organizations. Marine Policy, 13(2), 137-154. https://doi.org/10.1016/0308-597X(89)90004-3 Jentoft, S. (2000). The community: A missing link of fisheries management. Marine Policy, 24(1), 5359. https://doi.org/10.1016/S0308-597X(99)00009-3

Jentoft, S., \& McCay, B. (1995). User participation in fisheries management: lessons drawn from international experiences. Marine Policy, 19(3), 227-246. https://doi.org/10.1016/0308597X(94)00010-P 
Jentoft, S., McCay, B. J., \& Wilson, D. C. (1998). Social theory and fisheries co-management. Marine Policy, 22(4-5), 423-436. https://doi.org/10.1016/S0308-597X(97)00040-7

Kagel, J. H., Kim, C., \& Moser, D. (1996). Fairness in ultimatum games with asymmetric information and asymmetric payoffs. Games and Economic Behavior, 13(1), 100-110.

Kahnemann, D., \& Tversky, A. (1979). Prospect theory: An analysis of decision under risk. Econometrica, 47(2), 263-292.

Kauer, K., Bellquist, L., Gleason, M., Rubinstein, A., Sullivan, J., Oberhoff, D., Damrosch, L., Norvell, M., \& Bell, M. (2018). Reducing bycatch through a risk pool: A case study of the U.S. West Coast groundfish fishery. Marine Policy, 96, 90-99. https://doi.org/10.1016/j.marpol.2018.08.008

King, D. M., \& Sutinen, J. G. (2010). Rational noncompliance and the liquidation of Northeast groundfish resources. Marine Policy, 34(1), 7-21. https://doi.org/10.1016/j.marpol.2009.04.023

Klee, E., \& Kornhauser, L. A. (2007). Comparisons of the incentive for insolvency under different legal regimes. Journal of Legal Studies, 36(1), 141-170. https://doi.org/10.1086/509273

Kornhauser, L. A. (2013). Economic analysis of joint and several liability. In J. Arlen (Ed.), Research Handbook on the Economics of Torts (pp. 199-233).

Kornhauser, L. A., \& Revesz, R. L. (1994). Multidefendant Settlements: The Impact of Joint and Several Liability. The Journal of Legal Studies, 23(1), 41-76.

Kraak, S. B. M. (2011). Exploring the "public goods game" model to overcome the Tragedy of the Commons in fisheries management. Fish and Fisheries, 12(1), 18-33. https://doi.org/10.1111/j.1467-2979.2010.00372.x

Kronbak, L. G., \& Lindroos, M. (2006). An enforcement-coalition model: Fishermen and authorities forming coalitions. Environmental and Resource Economics, 35(3), 169-194. https://doi.org/10.1007/s10640-006-9012-4

Kuperan, K., \& Sutinen, J. G. (1998). Blue Water Crime: Deterrence, Legitimacy, and Compliance in 
Fisheries. Law \& Society Review, 32(2), 309. https://doi.org/10.2307/827765

Libecap, G. D. (1994). The Conditions for Successful Collective Action. Journal of Theoretical Politics, 6(4), 563-592. https://doi.org/10.1177/0951692894006004007

Little, A. S., Needle, C. L., Hilborn, R., Holland, D. S., \& Marshall, C. T. (2015). Real-time spatial management approaches to reduce bycatch and discards: Experiences from Europe and the United States. Fish and Fisheries, 16(4), 576-602. https://doi.org/10.1111/faf.12080

NAO. (2003). Fisheries enforcement in England. Report by the Comptroller and Auditor General; HC 563 Session 2002-2003. London.

National Archives and Records Administration. (2017). Magnuson-Stevens Act Provisions; Fisheries of the Northeastern United States; Northeast Multispecies Fishery; Disapproval of Northeast Fishery Sector IX Operational Plan. Federal Register Vol. 82, No. 224, 55522-55526.

Nielsen, J. R. (1994). Participation in Fishery Management Policy-Making - National and Ec Regulation of Danish Fishermen. Marine Policy, 18(1), 29-40. https://doi.org/10.1016/0308$597 \times(94) 90087-6$

Nielsen, J. R. (2003). An analytical framework for studying: compliance and legitimacy in fisheries management. Marine Policy, 27(5), 425-432.

Nielsen, J. R., \& Mathiesen, C. (2003). Important factors influencing rule compliance in fisheries lessons from Denmark. Marine Policy, 27(5), 409-416. https://doi.org/10.1016/S0308$597 \times(03) 00024-1$

Nielsen, J. R., \& Vedsmand, T. (1997). Fishermen's organisations in fisheries management. Perspectives for fisheries co-management based on Danish fisheries. Marine Policy, 21(3), 277288. https://doi.org/10.1016/S0308-597X(97)00010-9

Orensanz, J. M., Parma, A., Jerez, G., Barahona, N., Montecinos, M., \& Elias, I. (2005). What are the key elements for the sustainability of "S-fisheries"? insigths from south america. Bulletin of 
Marine Science, 76(2), 527-556.

Ostrom, E. (1990). Governing the commons: The evolution of institutions for collective action. Cambridge, Cambridge University Press.

Ostrom, E. (1995). Designing complexity to govern complexity. Property Rights and the Environment: Social and Ecological Issues, 33-45.

Ovando, D. A., Deacon, R. T., Lester, S. E., Costello, C., Van Leuvan, T., Mcllwain, K., ... Uchida, H. (2013). Conservation incentives and collective choices in cooperative fisheries. Marine Policy, 37(1), 132-140. https://doi.org/10.1016/j.marpol.2012.03.012

Parisi, F. (2000). The cost of the game: a taxonomy of social interactions. European Journal of Law and Economics, 9(2), 99-114.

Pauly, D., Christensen, V., Guénette, S., Pitcher, T. J., Sumaila, U. R., Walters, C. J., ... Zeller, D. (2002). Towards sustainability in world fisheries. Nature, 418(6898), 689-695. https://doi.org/10.1038/nature01017

Pinkerton, E. (2011). Co-operative management of local fisheries: new directions for improved management and community development. UBC Press.

Pinkerton, E., Allain, M., Decker, D., \& Carew, K. (2018). Atlantic and Pacific halibut co-management initiatives by Canadian fishermen's organizations. Fish and Fisheries. https://doi.org/10.1111/faf.12306

Pitcher, T. J., Watson, R., Forrest, R., Valtýsson, H. P., \& Guénette, S. (2002). Estimating illegal and unreported catches from marine ecosystems: A basis for change. Fish and Fisheries, 3(4), 317339. https://doi.org/10.1046/j.1467-2979.2002.00093.x

Polinsky, A. M., \& Shavell, S. (1979). The optimal tradeoff between the probability and magnitude of fines. American Economic Review, 69(5), 880-891. https://doi.org/10.2307/1813654

Polinsky, A. M., \& Shavell, S. (1992). Enforcement costs and the optimal magnitude and probability of 
fines. The Journal of Law and Economics, 35(1), 133-148.

Polinsky, A. M., \& Shavell, S. (1999). The Economic Theory of Public Law Enforcement (NBER No. 6993).

Pretty, J. (2003). Social Capital and the Collective Managementof Resources. Science, 302(12 December), 1912-1914.

Putnam, R. D. (2000). Bowling alone: The collapse and revival of American community. New York: New York: Simon and Schuster.

Segerson, K., \& Tietenberg, T. H. (1992). The structure of penalties in environmental enforcement: An economic analysis. Journal of Environmental Economics and Management, 23(2), 179-200. https://doi.org/10.1016/0095-0696(92)90028-U

Sekhar, N. U. (2007). Social capital and fisheries management: The case of Chilika Lake in India. Environmental Management, 39(4), 497-505. https://doi.org/10.1007/s00267-006-0183-0

Shavell, S. (1993). The optimal structure of law enforcement. The Journal of Law and Economics, 36(1, Part 2), 255-287.

Soma, K., van Tatenhove, J., \& van Leeuwen, J. (2015). Marine Governance in a European context: Regionalization, integration and cooperation for ecosystem-based management. Ocean and Coastal Management, 117, 4-13. https://doi.org/10.1016/j.ocecoaman.2015.03.010

Sumaila, U. R., Alder, J., \& Keith, H. (2006). Global scope and economics of illegal fishing. Marine Policy, 30(6), 696-703. https://doi.org/10.1016/j.marpol.2005.11.001

Sutinen, J. G., Gauvin, J. R., \& Gordon, D. V. (1989). An Enconometric Study of Regulatory Enforcement and Compliance in the Commercial Inshore Lobster Fishery of Massachusetts. Rights Based Fishing, 415-431.

Sutinen, J. G., \& Kuperan, K. (1999). A socio-economic theory of regulatory compliance. International Journal of Social Economics, 26, 174-193. https://doi.org/10.1108/03068299910229569 
Sutinen, J. G., Rieser, A., \& Gauvin, J. R. (1990). Measuring and explaining noncompliance in federally managed fisheries. Ocean Development and International Law, 21(3), 335-372.

https://doi.org/10.1080/00908329009545942

Tietenberg, T. H. (1989). Indivisible Toxic Torts: The Economics of Joint and Several Liability. Land Economics, 65(4), 305-319.

Tversky, A., \& Kahnemann, D. (1981). The framing of decisions and the psychology of choice. Science, 211(4481), 453-458.

Van Hoof, L. (2010). Co-management: An alternative to enforcement? ICES Journal of Marine Science, 67(2), 395-401. https://doi.org/10.1093/icesjms/fsp239

Veiga, P., Pita, C., Rangel, M., Gonçalves, J. M. S., Campos, A., Fernandes, P. G., ... Erzini, K. (2016). The EU landing obligation and European small-scale fisheries: What are the odds for success? Marine Policy, 64, 64-71. https://doi.org/10.1016/j.marpol.2015.11.008

Vestergaard, N. (2010). Principal-Agent Problems in Fisheries. In R. Q. Grafton (Ed.), Handbook of marine fisheries conservation and management (pp. 563-571). Oxford University Press. 
1 Table 1: Main characteristics of internal compliance systems in various fishery cooperative agreements in North America and in Europe

\begin{tabular}{|c|c|c|c|c|c|c|c|c|c|}
\hline $\begin{array}{l}\text { Cooperative } \\
\text { agreement } \\
\text { designation [number } \\
\text { of members] }\end{array}$ & Fishery & $\begin{array}{l}\text { Regulator's } \\
\text { jurisdiction and } \\
\text { governing law }\end{array}$ & $\begin{array}{l}\text { Joint and several liability } \\
\text { offenses }\end{array}$ & $\begin{array}{l}\text { Observation and } \\
\text { electronic } \\
\text { monitoring }\end{array}$ & $\begin{array}{l}\text { Reporting } \\
\text { requirements }\end{array}$ & Internal penalties & $\begin{array}{l}\text { Internal } \\
\text { enforcement } \\
\text { authority }\end{array}$ & Indemnification mechanisms & Additional considerations \\
\hline $\begin{array}{l}\text { Northeast fishery } \\
\text { sector II (NEFS II) [80] }\end{array}$ & $\begin{array}{l}\text { US North East } \\
\text { multispecies } \\
\text { fishery }\end{array}$ & $\begin{array}{l}\text { US federal, } \\
\text { NMFS } \\
\text { regulations }\end{array}$ & $\begin{array}{l}\text { Quota overages, } \\
\text { Misreporting of catches } \\
\text { landings and discards, } \\
\text { Discarding of legal-sized } \\
\text { fish }\end{array}$ & $\begin{array}{l}\text { At-sea eletronic } \\
\text { monitoring or actual } \\
\text { observer, dockside } \\
\text { observers (pre- } \\
\text { approved landing } \\
\text { stations) }\end{array}$ & $\begin{array}{l}\text { Catch logs, } \\
\text { dealer reports }\end{array}$ & $\begin{array}{l}\text { Monetary penalties } \\
\text { (ramping up for repeat } \\
\text { offense), stop fishing } \\
\text { order, expulsion }\end{array}$ & $\begin{array}{l}\text { Manager or } \\
\text { committee } \\
\text { appointed by the } \\
\text { Board }\end{array}$ & $\begin{array}{l}\text { Damages awarded to the } \\
\text { cooperative for overharvest is } \\
\text { distributed pro rata among the } \\
\text { members whose harvest was } \\
\text { reduced; violating party must } \\
\text { indemnify other parties against } \\
\text { governmental penalties }\end{array}$ & \\
\hline $\begin{array}{l}\text { Georges Bank cod } \\
\text { hook sector (GBCHS) } \\
{[20]}\end{array}$ & $\begin{array}{l}\text { US North East } \\
\text { multispecies } \\
\text { fishery }\end{array}$ & $\begin{array}{l}\text { US federal, } \\
\text { NMFS } \\
\text { regulations }\end{array}$ & $\begin{array}{l}\text { Quota overages, } \\
\text { Misreporting of catches } \\
\text { landings and discards, } \\
\text { Discarding of legal-sized } \\
\text { fish }\end{array}$ & $\begin{array}{l}\text { At-sea eletronic } \\
\text { monitoring or actual } \\
\text { observer, dockside } \\
\text { observers (pre- } \\
\text { approved landing } \\
\text { stations) }\end{array}$ & $\begin{array}{l}\text { Catch logs, } \\
\text { dealer reports }\end{array}$ & $\begin{array}{l}\text { Monetary penalties } \\
\text { (ramping up for repeat } \\
\text { offense), stop fishing } \\
\text { order, expulsion }\end{array}$ & $\begin{array}{l}\text { Manager or } \\
\text { committee } \\
\text { appointed by the } \\
\text { Board }\end{array}$ & $\begin{array}{l}\text { Violating members must indemnify } \\
\text { the other members in respect of } \\
\text { their respective losses; } \\
\text { indemnification shall be several and } \\
\text { not joint and several }\end{array}$ & \\
\hline $\begin{array}{l}\text { Whiting Mothership } \\
\text { Cooperative (WMC) } \\
\text { [35] }\end{array}$ & $\begin{array}{l}\text { US Pacific } \\
\text { whiting fishery }\end{array}$ & $\begin{array}{l}\text { US federal, } \\
\text { NMFS } \\
\text { regulations }\end{array}$ & $\begin{array}{l}\text { Quota overages, } \\
\text { violations of the } \\
\text { Cooperative's Non- } \\
\text { Whiting Species } \\
\text { management rules, non- } \\
\text { compliance with } \\
\text { observer requirements }\end{array}$ & $\begin{array}{l}\text { At-sea observers } \\
\text { (100\% coverage) }\end{array}$ & $\begin{array}{l}\text { Catch logs, } \\
\text { dealer reports }\end{array}$ & $\begin{array}{l}\text { Monetary penalties } \\
\text { (up to } 300 \% \text { of the ex- } \\
\text { vessel value of } \\
\text { landings), stop fishing } \\
\text { order, expulsion }\end{array}$ & $\begin{array}{l}\text { The Board or the } \\
\text { monitoring agent }\end{array}$ & $\begin{array}{l}\text { Damages awarded to the } \\
\text { cooperative for overharvest is } \\
\text { distributed pro rata among the } \\
\text { members whose harvest was } \\
\text { reduced; violating party must } \\
\text { indemnify other parties against } \\
\text { governmental penalties }\end{array}$ & $\begin{array}{l}\text { Members waive any claim } \\
\text { against the Manager and the } \\
\text { monitoring agent; members } \\
\text { are jointly and severally liable } \\
\text { for any third party claims } \\
\text { asserted against the Manager } \\
\text { or the monitoring agent }\end{array}$ \\
\hline $\begin{array}{l}\text { Alaska Catcher- } \\
\text { Processor } \\
\text { cooperatives - } \\
\text { incentive plan } \\
\text { agreement (CPIPA) } \\
\text { [24] }\end{array}$ & $\begin{array}{l}\text { Alaska pollock } \\
\text { fishery }\end{array}$ & $\begin{array}{l}\text { US federal, } \\
\text { NMFS } \\
\text { regulations }\end{array}$ & Quota overages & $\begin{array}{l}\text { At-sea observers } \\
\text { (100\% coverage) }\end{array}$ & Catch logs & $\begin{array}{l}\text { Monetary penalties } \\
\text { (ramping up for repeat } \\
\text { offense), stop fishing } \\
\text { order }\end{array}$ & $\begin{array}{l}\text { The technical } \\
\text { representative or } \\
\text { the coop } \\
\text { representatives } \\
\text { group }\end{array}$ & $\begin{array}{l}\text { No monetary damages for losses } \\
\text { associated with fishery shutdown; } \\
\text { collected penalties shall be used to } \\
\text { support research; indemnification } \\
\text { for legal fees }\end{array}$ & $\begin{array}{l}\text { spatial access incentives to } \\
\text { keep chinook bycatch low }\end{array}$ \\
\hline $\begin{array}{l}\text { Alaska Mothership } \\
\text { cooperatives - } \\
\text { incentive plan } \\
\text { agreement (MSIPA) } \\
\text { [19] }\end{array}$ & $\begin{array}{l}\text { Alaska pollock } \\
\text { fishery }\end{array}$ & $\begin{array}{l}\text { US federal, } \\
\text { NMFS } \\
\text { regulations }\end{array}$ & Quota overages & $\begin{array}{l}\text { At-sea observers } \\
\text { (100\% coverage) }\end{array}$ & Catch logs & $\begin{array}{l}\text { Monetary penalties, } \\
\text { penalties in quota } \\
\text { tonnes }\end{array}$ & $\begin{array}{l}\text { The technical } \\
\text { representative or } \\
\text { the coop } \\
\text { representatives } \\
\text { group }\end{array}$ & Unspecified & $\begin{array}{l}\text { collective and individual } \\
\text { chinook bycatch allocations }\end{array}$ \\
\hline $\begin{array}{l}\text { Alaska shoreside } \\
\text { cooperatives - } \\
\text { incentive plan } \\
\text { agreement (SIPA) [98] }\end{array}$ & $\begin{array}{l}\text { Alaska pollock } \\
\text { fishery }\end{array}$ & $\begin{array}{l}\text { US federal, } \\
\text { NMFS } \\
\text { regulations }\end{array}$ & Quota overages & $\begin{array}{l}\text { At-sea observers } \\
\text { (100\% coverage) }\end{array}$ & catch logs & $\begin{array}{l}\text { Monetary penalties } \\
\text { (ramping up for repeat } \\
\text { offense), stop fishing } \\
\text { order }\end{array}$ & $\begin{array}{l}\text { The technical } \\
\text { representative or } \\
\text { the coop } \\
\text { representatives } \\
\text { group }\end{array}$ & $\begin{array}{l}\text { No monetary damages for losses } \\
\text { associated with forgone pollock } \\
\text { fishing opportunities; } \\
\text { indemnification against } \\
\text { governmental penalties }\end{array}$ & bycatch risk pools \\
\hline
\end{tabular}


3 Table 1 (continued)

\begin{tabular}{|c|c|c|c|c|c|c|c|c|c|}
\hline $\begin{array}{l}\text { Cooperative } \\
\text { agreement } \\
\text { designation [number } \\
\text { of members] }\end{array}$ & Fishery & $\begin{array}{l}\text { Regulator's } \\
\text { jurisdiction and } \\
\text { governing law }\end{array}$ & $\begin{array}{l}\text { Joint and several liability } \\
\text { offenses }\end{array}$ & $\begin{array}{l}\text { Observation and } \\
\text { electronic } \\
\text { monitoring }\end{array}$ & $\begin{array}{l}\text { Reporting } \\
\text { requirements }\end{array}$ & Internal penalties & $\begin{array}{l}\text { Internal } \\
\text { enforcement } \\
\text { authority }\end{array}$ & Indemnification mechanisms & Additional considerations \\
\hline $\begin{array}{l}\text { Fundy fixed gear } \\
\text { council - Community } \\
\text { Harvest Plan (FCHP) } \\
\text { [64] }\end{array}$ & $\begin{array}{l}\text { Canada Scotia- } \\
\text { Fundy inshore } \\
\text { groundfish } \\
\text { fishery }\end{array}$ & $\begin{array}{l}\text { Canada, DFO } \\
\text { regulations }\end{array}$ & Quota overages & $\begin{array}{l}\text { Dockside monitoring } \\
\text { 'hail-out hail-in' } \\
\text { program (100\% } \\
\text { landings), at-sea } \\
\text { observers (at least } \\
10 \%)\end{array}$ & $\begin{array}{l}\text { Electronic } \\
\text { logbooks }\end{array}$ & $\begin{array}{l}\text { Reduction in quota } \\
\text { and/or time at sea, } \\
\text { temporary or } \\
\text { permanent expulsion }\end{array}$ & $\begin{array}{l}\text { Community } \\
\text { Management Board }\end{array}$ & Unspecified & \\
\hline $\begin{array}{l}\text { Les Pêcheurs de } \\
\text { Bretagne producer } \\
\text { organization - articles } \\
\text { of association } \\
\text { (PDBPO) [800] }\end{array}$ & $\begin{array}{l}\text { Western Europe } \\
\text { whitefish } \\
\text { species and } \\
\text { nephrops } \\
\text { fisheries }\end{array}$ & $\begin{array}{l}\text { France, CFP } \\
\text { regulations and } \\
\text { national } \\
\text { fisheries law }\end{array}$ & Quota overages & $\begin{array}{l}\text { At-sea eletronic } \\
\text { monitoring }\end{array}$ & $\begin{array}{l}\text { Catch logs, } \\
\text { dealer reports }\end{array}$ & $\begin{array}{l}\text { Monetary penalties } \\
\text { (up to } 100 \% \text { of the ex- } \\
\text { vessel value of non- } \\
\text { compliant landings), } \\
\text { stop fishing order, } \\
\text { expulsion }\end{array}$ & $\begin{array}{l}\text { The Board or the } \\
\text { president }\end{array}$ & Unspecified & \\
\hline $\begin{array}{l}\text { Cobrenord producer } \\
\text { organization - internal } \\
\text { agreement (CNPO) } \\
{[210]}\end{array}$ & $\begin{array}{l}\text { Western Europe } \\
\text { whitefish } \\
\text { species and } \\
\text { scallop fisheries }\end{array}$ & $\begin{array}{l}\text { France, CFP } \\
\text { regulations and } \\
\text { national } \\
\text { fisheries law }\end{array}$ & Quota overages & $\begin{array}{l}\text { At-sea eletronic } \\
\text { monitoring }\end{array}$ & $\begin{array}{l}\text { Catch logs, } \\
\text { dealer reports }\end{array}$ & $\begin{array}{l}\text { Seizure of catch, stop } \\
\text { fishing order, } \\
\text { expulsion }\end{array}$ & The Board & Unspecified & No monetary penalty \\
\hline $\begin{array}{l}\text { FROM nord producer } \\
\text { organization - internal } \\
\text { agreement (FNPO) } \\
{[200]}\end{array}$ & $\begin{array}{l}\text { Western Europe } \\
\text { whitefish } \\
\text { species and } \\
\text { scallop fisheries }\end{array}$ & $\begin{array}{l}\text { France, CFP } \\
\text { regulations and } \\
\text { national } \\
\text { fisheries law }\end{array}$ & Quota overages & $\begin{array}{l}\text { At-sea eletronic } \\
\text { monitoring }\end{array}$ & $\begin{array}{l}\text { Catch logs, } \\
\text { dealer reports }\end{array}$ & $\begin{array}{l}\text { Monetary penalties } \\
\text { (equal to } 100 \% \text { of the } \\
\text { ex-vessel value of } \\
\text { landings), stop fishing } \\
\text { order, expulsion }\end{array}$ & The Board & $\begin{array}{l}\text { Damages awarded to the PO for } \\
\text { overharvest is distributed pro rata } \\
\text { among the members whose harvest } \\
\text { was reduced }\end{array}$ & $\begin{array}{l}\text { Deposit may be required } \\
\text { during the course of the fishing } \\
\text { season if quota utilization rate } \\
\text { is higher than } 80 \%\end{array}$ \\
\hline $\begin{array}{l}\text { Cooperative } \\
\text { association of Brown } \\
\text { shrimp producer } \\
\text { organizations - } \\
\text { management plan } \\
\text { (BSMP) [225] }\end{array}$ & $\begin{array}{l}\text { North Sea } \\
\text { brown shrimp } \\
\text { fishery }\end{array}$ & $\begin{array}{l}\text { The } \\
\text { Netherlands, } \\
\text { CFP regulations } \\
\text { and national } \\
\text { fisheries law }\end{array}$ & Quota overages & $\begin{array}{l}\text { At-sea eletronic } \\
\text { monitoring, } \\
\text { dockside observers } \\
\text { (pre-approved } \\
\text { landing stations) }\end{array}$ & $\begin{array}{l}\text { Catch logs, } \\
\text { dealer reports }\end{array}$ & $\begin{array}{l}\text { Monetary penalties up } \\
\text { to } € 250,000\end{array}$ & The Board & Unspecified & $\begin{array}{l}\text { MSC management plan and } \\
\text { certificate }\end{array}$ \\
\hline $\begin{array}{l}\text { Thorupstrand Coastal } \\
\text { Fishermen's Guild - } \\
\text { articles of association } \\
\text { (TCFG) [11] }\end{array}$ & $\begin{array}{l}\text { North Sea } \\
\text { whitefish } \\
\text { species coastal } \\
\text { fishery }\end{array}$ & $\begin{array}{l}\text { Denmark, CFP } \\
\text { regulation and } \\
\text { national } \\
\text { fisheries law }\end{array}$ & Quota overages & $\begin{array}{l}\text { Inspections at-sea } \\
\text { and onshore, supply } \\
\text { chain monitoring }\end{array}$ & $\begin{array}{l}\text { Logbook } \\
\text { declarations }\end{array}$ & $\begin{array}{l}\text { Deductions in quota } \\
\text { shares, monetary } \\
\text { penalties, expulsion }\end{array}$ & $\begin{array}{l}\text { The Manager or the } \\
\text { General Meeting }\end{array}$ & Unspecified & $\begin{array}{l}\text { 'Fishpool' arrangements that } \\
\text { facilitate in-season quota } \\
\text { leasing; deposit required upon } \\
\text { initial membership to cover } \\
\text { potential damages }\end{array}$ \\
\hline $\begin{array}{l}\text { Aberdeen fish } \\
\text { producer organization } \\
\text { - articles of } \\
\text { association (AFPO) } \\
\text { [19] }\end{array}$ & $\begin{array}{l}\text { Western Europe } \\
\text { whitefish } \\
\text { species and } \\
\text { nephrops } \\
\text { fisheries }\end{array}$ & $\begin{array}{l}\text { United } \\
\text { Kingdom, CFP } \\
\text { regulations and } \\
\text { national } \\
\text { fisheries law }\end{array}$ & Quota overages & $\begin{array}{l}\text { At-sea eletronic } \\
\text { monitoring }\end{array}$ & $\begin{array}{l}\text { E-logs and e- } \\
\text { declarations }\end{array}$ & $\begin{array}{l}\text { Monetary penalties up } \\
\text { to } f 250,000 \text {, penalties } \\
\text { in quota tonnes, } \\
\text { expulsion, loss of } \\
\text { quota units }\end{array}$ & $\begin{array}{l}\text { Disciplinary } \\
\text { committee } \\
\text { appointed by the } \\
\text { Board }\end{array}$ & Unspecified & \\
\hline
\end{tabular}


